\title{
Temporal variation in prevalence, awareness and control of hypertension in urban and rural areas in Northeast Brazil between 2006 and 2016
}

\section{Variação temporal na prevalência, conhecimento e controle da hipertensão arterial em áreas urbanas e rurais do Nordeste brasileiro entre 2006 e 2016}

\section{Variación temporal de la prevalencia, concienciación y control de la hipertensión en áreas urbanas y rurales en el nordeste brasileño entre 2006 y 2016}

\author{
Nathália Paula de Souza 1,2 \\ Eduarda Ângela Pessoa Cesse 1 \\ Wayner Vieira de Souza 1 \\ Annick Fontbonne 3 \\ Maria Nelly Sobreira de Carvalho Barreto 1 \\ Mélanie Le Goff 4 \\ Malaquias Batista Filho 5 \\ Catherine Féart 4 \\ Pedro Israel Cabral de Lira 6
}

\begin{abstract}
To assess the evolution in prevalence, awareness and control of hypertension for over 10 years in Pernambuco State, Northeast Brazil, two cross-sectional studies were conducted based on random samples of households in urban and rural areas, in 2006 and 2015/2016, involving adults aged 20 years or older. Hypertension was defined as systolic blood pressure of at least $140 \mathrm{mmHg}$ or diastolic blood pressure of at least $90 \mathrm{mmHg}$ as well as the reported use of antihypertensive medication. A logistic regression analysis was conducted to estimate the influence of the social, behavioral and anthropometric determinants on hypertension. Although social and behavioral factors improved in this 10-year period, overweight and abdominal obesity increased. Approximately one third of the adult population of Pernambuco had hypertension in 2006 and this prevalence was maintained in 2015/2016. In rural areas, awareness concerning hypertension rose from 44.8\% in 2006 to 67.3\% in 2015/2016, and control from $5.3 \%$ to $27.1 \%$, so that awareness and control were similar in urban and rural areas in 2015/2016. After an adjustment for potential confounding factors, the likelihood of having hypertension more than doubled among men $(O R=2.03 ; p<0.001)$, middle $(O R=4.41 ; p<0.001)$ and oldage subjects $(O R=14.44 ; p<0.001)$, and those who had abdominal obesity $(O R=2.04 ; p<0.001)$ in urban areas and among middle-aged $(O R=2.56$; $p<0.001)$, less educated individuals $(O R=2.21 ; p=0.006)$ and those who were overweight $(O R=2.23 ; p<0.001)$ in rural areas. Despite the favorable evolution in the management of hypertension in Pernambuco, public health measures focused in vulnerable populations are still required, mainly in rural areas, to improve primary prevention and decrease the disease rate.
\end{abstract}

Hypertension; Prevalence; Awareness; Control; Adult

\author{
Correspondence \\ N. P. Souza \\ Rua Francisco Lacerda 90, bloco A, apto. 302, Recife, PE \\ 50741-150, Brasil. \\ n.paula.souza@gmail.com \\ ${ }^{1}$ Instituto Aggeu Magalhães, Fundação Oswaldo Cruz, Recife, \\ Brasil. \\ 2 Centro Acadêmico de Vitória, Universidade Federal de \\ Pernambuco, Vitória de Santo Antão, Brasil. \\ 3 Centre de Recherche en Epidémiologie et Santé des Populations, \\ INSERM, Villejuif, France. \\ 4 Université de Bordeaux, Bordeaux, France. \\ 5 Instituto de Medicina Integral Professor Fernando Figueira, \\ Recife, Brasil. \\ 6 Departamento de Nutrição, Universidade Federal de \\ Pernambuco, Recife, Brasil.
}




\section{Introduction}

The social, human and economic impacts of noncommunicable diseases, especially cardiovascular disorders 1,2,3, led the United Nations to invite heads of state to debate the issue in 2011. This highlevel meeting resulted in a global action plan to prevent and control these diseases, including global goals and monitoring indicators to cut by $25 \%$ premature mortality related to cardiovascular diseases by 2025 , highlighting the reduction and prevention of raised blood pressure.

In 2016, high systolic blood pressure was the second greatest risk factor for disability-adjusted life-years for men and the first for women at global level 5, as well as the second greatest in Brazil 6. Data from May Measurement Month 2017 showed that hypertension prevalence was 34.9\% in the world 7 and the Brazilian National Health Survey determined a prevalence of $22.8 \%$ for raised blood pressure 8 .

Worldwide, awareness, treatment and control of high blood pressure are markedly higher in urban areas 9,10. In 2010, only $15.6 \%$ of the Brazilian population lived in rural areas. However, in the case of the Northeast region of the country, which contains 9 of its 27 states, the percentage of rural population was $26.9 \% 11$. Pernambuco, the second most populous state in the Northeast region of Brazil, had a 0.54 Human Development Index (HDI) in 2000 and 0.67 in 2010, always below national average 12. The metropolitan region of Recife, capital of the State of Pernambuco, presented the third greater difference on the HDI educational indices between urban and rural areas in 201013 , emphasizing the inequalities within and between regions. Therefore, the country improvements were disproportionate, maintaining the same vulnerable groups and areas 14.

A recent systematic review pointed a higher risk of hypertension among lowest socioeconomic status individuals, mainly in low educational level 15 . This relationship had been consistently reaffirmed in high income countries (HICs) 15,16, altough low and middle-income countries (LMICs) have documented only little and unclear evidence. Databases research on LMICs rural populations showed a positive association between income and hypertension, but it varied according to geographical region 17. A negative relationship was observed in Latin America 15 and in a national study from Brazil 18. The positive association was explained by the theory that economic progress and urbanization increase the risk factors for hypertension (obesity, sedentary lifestyle, high salt intake), whereas the negative can be explained by the decrease of the risk factors 19 .

Since 2002, in Brazil, redistributive policies of social assistance were implemented, improving health, reducing social inequalities and alleviating poverty 20 . Thus, the aim of this study was to characterize the evolution in hypertension prevalence, awareness and control in adults of a poor region of Northeast Brazil, between 2006 and 2015/2016, a period of social and health reforms in the country. In addition, it intended to relate the evolution of hypertension to sociodemographic, behavioral and anthropometric determinants, contrasting urban and rural areas.

\section{Methods}

\section{Study design and population}

Data from the State Surveys of Noncommunicable Diseases were used in this study. Two cross-sectional surveys were carried out based on random samples of households in urban and rural areas of the State of Pernambuco, one in 2006, involving adults aged 25 years and above, and the other from 2015 to 2016, on subjects of 20 years and above.

In 2006, the estimated sample size was nearly 800 adults in urban and rural areas, with a $3 \%$ precision error, 25\% hypertension prevalence and 95\% confidence interval (95\%CI). In 2015/2016, the estimated sample size was 806 adults in urban areas and 310 in rural areas, with a $3.1 \%$ to $5 \%$ precision error, $28 \%$ hypertension prevalence and a $95 \% \mathrm{CI}$.

The sample was representative of both urban and rural areas and was obtained by four-stage cluster sampling. First, municipalities were selected, then census tracts, households and, finally, the subject. In total, 18 municipalities were selected in 2006 and 13 in 2015/2016. The municipalities 
were selected randomly in 2006 and conveniently maintained in the second survey (2015/2016). Five cities were reduced in 2015/2016 due to financial difficulties and randomly excluded.

The census tracts were carried out according to the distribution of the urban and rural population of each municipality, based on the 2000 and 2010 Brazilian Demographic Censuses. Twenty census tracts of the urban areas were randomly selected in both 2006 and 2015/2016. In the rural areas, 19 census tracts were selected in 2006 and 9 in 2015/2016. Within each selected census tract, eligible households were mapped and approximately 40 , with equal probabilities, were elected. At least one adult from each household was randomly chosen to participate in the study. The starting point of data collection was the same adopted by the demographic census. The data were collected through interviews, performed by previously trained professionals and using a standardized questionnaire.

The surveys were conducted according to the prevailing ethical recommendations, and approved by the Human Research Ethics Committee of the Institute of Integral Medicine Professor Fernando Figueira, in 2006, under the n. 709/2006 and by the Research Ethics Committee of the Health Sciences Center of the Federal University of Pernambuco, in 2015/2016, under the n. 07803512.9.0000.5208. Moreover, each participant provided a signed informed consent.

\section{Sociodemographic, measurements and lifestyle data collection}

Sociodemographic indicators were categorized as follows: age (20-39, 40-59, $\geq 60$ years); sex; housing area (urban and rural); years of schooling $(<8,8-11$ and $\geq 12$ years); and working conditions (employed, unemployed, retired/pensioner).

Anthropometric measures were performed in duplicate by trained professionals, respecting techniques recommended by the World Health Organization (WHO). A digital scale accurate to $0.1 \mathrm{~kg}$ and $150 \mathrm{~kg}$ capacity and a portable stadiometer (Alturaexata Ltda., Belo Horizonte, Brazil) accurate to $0.1 \mathrm{~cm}$ were used. Body mass index (BMI) was considered adequate when below $25 \mathrm{~kg} / \mathrm{m}^{2}$ for people under 60 years old, and $27 \mathrm{~kg} / \mathrm{m}^{2}$ for those of 60 years old and older 21 . Waist circumference was measured according to recommended 22 and it was considered an indicative of cardiovascular risk values equal or higher than $94 \mathrm{~cm}$ for men and $80 \mathrm{~cm}$ for female subjects 21,23 .

Over 2 drinks per day for male and 1 drink for female subjects was considered high alcohol consumption ${ }^{21}$. Non-smoking category included people who reported having never smoked and ex-smokers.

Physical activity level was assessed using the International Physical Activity Questionnaire (IPAQ) (short form) and classified according to the WHO global recommendations on physical activity for health 24. Sufficiently active corresponds to at least 150 minutes of moderate-intensity aerobic physical activity, or at least 75 minutes of vigorous-intensity aerobic physical activity throughout the week, or an equivalent combination of moderate and vigorous-intensity activity of 450 to 750 MET (metabolic equivalents) 24.

\section{Blood pressure}

Blood pressure measurement was performed in duplicate by healthcare professionals using a mercury column sphygmomanometer (model Glicomed-CE-0483, Accumed, Duque de Caxias, Brazil) and obeying the VII Brazilian Arterial Hypertension Guideline 21.

Subjects with systolic blood pressure (SBP) of at least $140 \mathrm{mmHg}$ and/or diastolic blood pressure (DBP) of at least $90 \mathrm{mmHg}$, or those who reported antihypertensive medication use, were considered hypertensive. When they self-reported a previous diagnosis of hypertension made by a healthcare professional, hypertensive subjects were classified as aware. Control of hypertension among the hypertensive subjects was defined as SBP and DBP below $140 \mathrm{mmHg}$ and $90 \mathrm{mmHg}$, respectively.

\section{Statistical analysis}

Statistical analyses were performed using IBM SPSS Statistics for Windows, version 19 (https://www. $\mathrm{ibm} . \mathrm{com} /$ ). Initially, a stratified analysis was performed per year of study and housing area to describe the sample and identify significant changes in social determinants and behavioral and anthropometric 
risk factors over the 10 years between the surveys. In addition, the chi-square test was used to verify differences on hypertension prevalence between and within each search, in urban and rural areas of the State of Pernambuco. Next, variation in awareness and blood pressure control between 2006 and 2015/2016 were compared using chi-square, by housing area.

Finally, the relations between social, behavioral and anthropometric determinants and the prevalence of hypertension were tested using multivariate logistic regression analysis and backward stepwise selection method. This analysis was controlled for the research year and adjusted odds ratios (ORs) with 95\%CI were calculated to assess the risk of independent variables. Considering that the determinants of this study have a relationship with hypertension that was already consolidated in the literature, all variables were included in the logistic regression. The criteria to remove variables in each step of the selection was $\mathrm{p}>0.10$.

\section{Results}

In total, 1,644 subjects participated in the 2006 survey, and 1,201 in 2015/2016. In 2006, there were 142 subjects with insufficient data, due to the absence or inconsistency of anthropometric information, and 148 in 2015/2016. As a result, there were 1,502 and 1,053 subjects in the multivariate analyses. Among these, 1,530 were in urban (50.3\% on 2006 survey and $49.7 \%$ on 2015/2016) and 1,025 in rural (71.5\% on 2006 survey and $28.5 \%$ on $2015 / 2016)$ areas.

In 2006, $8.4 \%$ of the totality of samples was made up by 60 years old or older people, whereas in $2015 / 2016$ it was made up by $13.5 \%$ of them, with a significant increase in both urban and rural areas in the same period. The urban population rose from around $52 \%$ to $73 \%$ (Table 1).

Although the percentage of participants that had less than eight years of schooling decreased from $72.6 \%$ in 2006 to $54.7 \%$ in 2015/2016 it corresponded to $70.6 \%$ in rural areas and $48.7 \%$ in urban areas in $2015 / 2016$. On the other hand, the prevalence of overweight significantly increased $(50.9 \%$ in 2006 to $64.7 \%$ in 2015/2016). Abdominal obesity increased by $19.3 \%$ in the rural areas and $11.9 \%$ in the urban areas (Table 1).

The prevalence of smokers and high alcohol consumers decreased in both urban and rural areas. The proportion of sufficiently active people increased between the 2006 and 2015/2016 in urban but not in rural populations (Table 1).

Hypertension prevalence did not significantly differ between 2006 (33.1\%; 95\%CI: 30.9-35.5) and 2015/2016 (33.5\%; 95\%CI: 30.8-36.3), although in 2006 it was significantly higher in rural areas (35.7\%; 95\%CI: 32.1-39.0) when compared to urban areas (30.7\%; 95\%CI: 27.6-34.2) ( $\mathrm{p}=0.034)$. In 2015/2016 there was no difference between them (rural $=32.4 \%$; 95\%CI: $27.2-37.3 /$ urban $=33.9 \%$; 95\%CI: 30.7-37.1) (Figure 1).

The awareness of the condition of hypertension in rural areas rose from $44.8 \%$ (95\%CI: 39.1-51.1) in 2006 to $67.3 \%$ (95\%CI: 58.0-76.2) in 2015/2016, and blood pressure control from 5.3\% (95\%CI: 3.0-8.1) to $27.1 \%$ (95\%CI: $18.0-35.5$ ) during the same period. In 2015/2016, 68.8\% (95\%CI: $63.3-74.0$ ) subjects with hypertension in urban areas were aware of their condition and 33.2\% (95\%CI: 27.8-38.1) had their blood pressure controlled. The difference in awareness and control between urban and rural areas was significant in 2006, but not in 2015/2016 (Figure 1).

In urban areas, hypertension prevalence increased among female and people with lowest levels of education between 2006 and 2015/2016. In rural areas, it decreased among the youngest, those who presented a normal waist circumference and those who were sufficiently active. Overall, there was an inverse association between hypertension prevalence and educational level, and a proportional association with age (Table 2).

After adjustment for the year of research and other sociodemographic and lifestyle determinants, middle-age category, male, lowest levels of education, overweight and abdominal obesity were all independently and positively associated with arterial hypertension in urban and rural areas. Being middle-aged increased 2.56 and 4.41 times the chance of being hypertensive in rural and urban areas, respectively. Furthermore, high alcohol intake in rural areas was another independent risk factor for hypertension (Table 3). 
Table 1

Description of the sociodemographic, anthropometric measurements and lifestyle data of the adult population of the total sample and the rural and urban samples from 2006 to 2015/2016. State Surveys of Noncommunicable Diseases, Pernambuco State, Brazil.

\begin{tabular}{|c|c|c|c|c|c|c|c|c|c|}
\hline \multirow[t]{2}{*}{ Variables } & \multicolumn{3}{|c|}{ Total sample n (\%) } & \multicolumn{3}{|c|}{ Rural n (\%) } & \multicolumn{3}{|c|}{ Urban n (\%) } \\
\hline & 2006 & $2015 / 2016$ & p-value * & 2006 & 2015/2016 & p-value * & 2006 & 2015/2016 & p-value * \\
\hline \multicolumn{10}{|l|}{ Sociodemographic conditions } \\
\hline Age (years) & & & $<0.001$ & & & $<0.001$ & & & $<0.001$ \\
\hline $20 \mid-40$ & $1,093(66.5)$ & 649 (54.0) & & $540(68.5)$ & $182(55.2)$ & & $553(64.6)$ & $467(53.6)$ & \\
\hline $40 \mid-60$ & $413(25.1)$ & $390(32.5)$ & & $197(25.0)$ & $107(32.4)$ & & $216(25.2)$ & $283(32.5)$ & \\
\hline$\geq 60$ & $138(8.4)$ & $162(13.5)$ & & $51(6.5)$ & $41(12.4)$ & & $87(10.2)$ & $121(13.9)$ & \\
\hline Sex & & & 0.004 & & & 0.072 & & & 0.155 \\
\hline Male & $693(42.2)$ & $442(36.8)$ & & $359(45.6)$ & $131(39.7)$ & & $334(39.0)$ & $311(35.7)$ & \\
\hline Female & $951(57.8)$ & 759 (63.2) & & $429(54.4)$ & $199(60.3)$ & & $522(61.0)$ & $560(64.3)$ & \\
\hline Housing area & & & $<0.001$ & & & & & & \\
\hline Rural & 788 (47.9) & $330(27.5)$ & & - & - & & - & - & \\
\hline Urban & $856(52.1)$ & $871(72.5)$ & & - & - & & - & - & \\
\hline Education (years of schooling) & & & $<0.001$ & & & $<0.001$ & & & $<0.001$ \\
\hline$\geq 12$ & $293(17.8)$ & 357 (29.7) & & $57(7.2)$ & $52(15.8)$ & & $236(27.6)$ & $305(35.0)$ & \\
\hline $8 \mid-12$ & $157(9.6)$ & $187(15.6)$ & & $38(4.8)$ & $45(13.6)$ & & 119 (13.9) & $142(16.3)$ & \\
\hline$<8$ & $1,194(72.6)$ & $657(54.7)$ & & $693(88.0)$ & $233(70.6)$ & & $501(58.5)$ & $424(48.7)$ & \\
\hline Working condition & & & $<0.001$ & & & 0.001 & & & $<0.001$ \\
\hline Employed & $368(22.4)$ & 357 (29.7) & & $171(21.7)$ & $98(29.7)$ & & $197(23.0)$ & $259(29.8)$ & \\
\hline Unemployed & $763(46.4)$ & 635 (52.9) & & $404(51.3)$ & $173(52.4)$ & & 359 (41.9) & $462(53.0)$ & \\
\hline Retired/Pensioner & $513(31.2)$ & 209 (17.4) & & $213(27.0)$ & $59(17.9)$ & & $300(35.1)$ & $150(17.2)$ & \\
\hline \multicolumn{10}{|l|}{ Anthropometric measures } \\
\hline Overweight/Obesity ** & & & $<0.001$ & & & 0.001 & & & $<0.001$ \\
\hline No & $738(49.1)$ & $372(35.3)$ & & $396(54.0)$ & $125(42.8)$ & & $342(44.5)$ & $247(32.5)$ & \\
\hline Yes & 764 (50.9) & $681(64.7)$ & & $337(46.0)$ & $167(57.2)$ & & $427(55.5)$ & $514(67.5)$ & \\
\hline Abdominal obesity & & & $<0.001$ & & & $<0.001$ & & & $<0.001$ \\
\hline No & $769(47.0)$ & $362(30.4)$ & & $420(53.6)$ & $112(34.3)$ & & 349 (40.9) & $250(29.0)$ & \\
\hline Yes $(\geq 94 \mathrm{~cm}$ ô or $\geq 80 \mathrm{~cm}$ q) & $867(53.0)$ & 827 (69.6) & & $363(46.4)$ & $215(65.7)$ & & $504(59.1)$ & $612(71.0)$ & \\
\hline \multicolumn{10}{|l|}{ Lifestyle } \\
\hline High alcohol consumption $* \star \star$ & & & $<0.001$ & & & 0.004 & & & 0.002 \\
\hline No & $1,155(70.3)$ & $915(76.2)$ & & $579(73.5)$ & $269(81.5)$ & & $576(67.3)$ & $646(74.2)$ & \\
\hline Yes & $489(29.7)$ & $286(23.8)$ & & $209(26.5)$ & $61(18.5)$ & & $280(32.7)$ & $225(25.8)$ & \\
\hline Smoker & & & $<0.001$ & & & 0.039 & & & $<0.001$ \\
\hline No & $1,268(77.1)$ & $1,012(84.3)$ & & $590(74.9)$ & $266(80.6)$ & & $678(79.2)$ & $746(85.6)$ & \\
\hline Yes & $376(22.9)$ & $189(15.7)$ & & $198(25.1)$ & $64(19.4)$ & & $178(20.8)$ & $125(14.4)$ & \\
\hline Physical activity & & & $<0.001$ & & & 0.225 & & & $<0.001$ \\
\hline Sufficiently active & $918(55.8)$ & $813(67.7)$ & & $505(64.1)$ & 224 (67.9) & & $413(48.2)$ & 589 (67.6) & \\
\hline Insufficiently active & 726 (44.2) & 388 (32.3) & & $283(35.9)$ & $106(32.1)$ & & $443(51.8)$ & $282(32.4)$ & \\
\hline
\end{tabular}

* Pearson's chi-square test;

** BMI: body mass index $\geq 25 \mathrm{~kg} / \mathrm{m}^{2}$ for people under 60 years and $\geq 27 \mathrm{~kg} / \mathrm{m}^{2}$ for those of 60 years of age and older;

$\star * \star$ High alcohol consumption: $>2$ drinks per day for male and $>1$ drink per day for female subjects. 
Figure 1

Variation in the prevalence, awareness and control of hypertension in urban and rural areas of the Pernambuco State, Brazil, between 2006 and 2015/2016

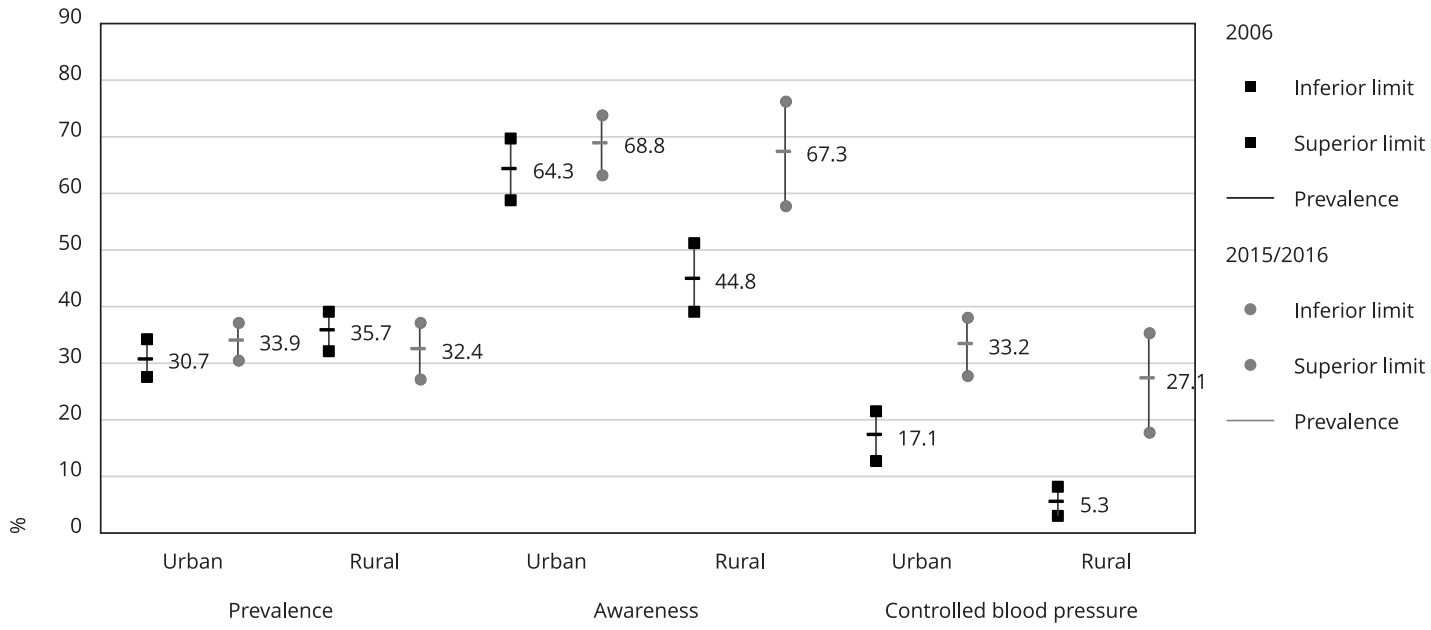

Note: awareness and control were mensured among hypertensives individuals $(\mathrm{N}=960)$

\section{Discussion}

The prevalence of hypertension among adults of the state of Pernambuco steadily remained around 33\% from 2006 to 2015/2016. Age, schooling, BMI, waist circumference and sex were independent determinants of hypertension in rural and urban areas, after adjustment for confounding factors. The youngest subjects, less educated and overweight, living in rural areas, and male subjects , middle and old-age and who had abdominal obesity, living in urban areas were twice as likely to be hypertensive, after adjustment for confounding factors.

Worldwide, $34.9 \%$ of the adults had hypertension in 2015/2016 7, similar to the findings of this study. The number is higher than the presented in other national studies that used blood pressure measurement only to define hypertension 8 and even greater in relation to studies that used selfreported information only 18,25 . However, it is lower than presented in local studies using the same criterion as this one $26,27,28$. This heterogeneity reflects varied survey methodologies and the differences in the population profiles, outlining the importance of studies that elucidate locations-specific risk factors and disease burden, mainly in developing regions, where strong social and economic disparities exist between and within countries 17,29.

Surprisingly, despite the population aging, recognized as an important determinant of increased blood pressure 30, between 2006 and 2015/2016 surveys, hypertension prevalence did not increase. Therefore, the findings of this study confront the trend of rising hypertension in LMICs, where prevalence increased $7.7 \%$ from 2000 to 2010 , according to a systematic analysis of population-based studies 31 . However, it confirms a recent pooled analysis of 200 countries that suggests that decreasing trends might have begun in some middle-income regions 30 .

The information bias by self-reported answers and the study design, that did not allow the identification of new cases, may have underrated or offset an increasing on hypertension prevalence, essentially in the rural region, compromising the understanding of the real dimension of hypertension growth in the state. The insertion of younger subjects (20-24 years old) in the 2015/2016 survey may also have had the same effect. On the other hand, hypertension is an asymptomatic disease in its 
Table 2

Variation in the prevalence of arterial hypertension of the adult population of the total sample and the rural and urban samples from 2006 to $2015 / 2016$ in relation to sociodemographic, anthropometric and lifestyle data. State Surveys of Noncommunicable Diseases, Pernambuco State, Brazil.

\begin{tabular}{|c|c|c|c|c|c|c|c|c|c|}
\hline \multirow[t]{2}{*}{ Variables } & \multicolumn{3}{|c|}{ Total sample n (\%) } & \multicolumn{3}{|c|}{ Rural n (\%) } & \multicolumn{3}{|c|}{ Urban n (\%) } \\
\hline & 2006 & $2015 / 2016$ & p-value * & 2006 & $2015 / 2016$ & p-value * & 2006 & $2015 / 2016$ & p-value * \\
\hline \multicolumn{10}{|l|}{ Sociodemographic } \\
\hline \multicolumn{10}{|l|}{ conditions } \\
\hline \multicolumn{10}{|l|}{ Age (years) } \\
\hline $20 \mid-40$ & $242(22.1)$ & 89 (13.7) & $<0.001$ & $148(27.4)$ & $28(15.4)$ & 0.001 & $94(17.0)$ & $61(13.1)$ & 0.081 \\
\hline $40 \mid-60$ & $198(47.9)$ & $183(46.9)$ & 0.773 & $97(49.2)$ & $50(46.7)$ & 0.676 & $101(46.8)$ & $133(47.0)$ & 0.958 \\
\hline$\geq 60$ & $104(75.4)$ & $130(80.2)$ & 0.309 & $36(70.6)$ & $29(70.7)$ & 0.988 & $68(78.2)$ & $101(83.5)$ & 0.333 \\
\hline p-value ** & $<0.001$ & $<0.001$ & & $<0.001$ & $<0.001$ & & $<0.001$ & $<0.001$ & \\
\hline \multicolumn{10}{|l|}{ Gender } \\
\hline Male & $279(40.3)$ & 148 (33.5) & 0.022 & $148(41.2)$ & $45(34.4)$ & 0.168 & $131(39.2)$ & $103(33.1)$ & 0.107 \\
\hline Female & 265 (27.9) & $254(33.5)$ & 0.012 & $133(31.0)$ & $62(31.2)$ & 0.979 & $132(25.3)$ & $192(34.3)$ & 0.001 \\
\hline p-value ** & $<0.001$ & 0.995 & & 0.003 & 0.544 & & $<0.001$ & 0.727 & \\
\hline \multicolumn{10}{|l|}{$\begin{array}{l}\text { Education (years of } \\
\text { schooling) }\end{array}$} \\
\hline$\geq 12$ & $62(21.2)$ & $67(18.8)$ & 0.447 & $11(19.3)$ & $8(15.4)$ & 0.591 & $51(21.6)$ & $59(19.3)$ & 0.516 \\
\hline $8 \mid-12$ & $35(22.3)$ & $38(20.3)$ & 0.656 & $9(23.7)$ & $4(8.9)$ & 0.065 & $26(21.8)$ & 34 (23.9) & 0.689 \\
\hline$<8$ & $447(37.4)$ & $297(45.2)$ & 0.001 & $261(37.7)$ & $95(40.8)$ & 0.399 & $186(37.1)$ & $202(47.6)$ & 0.001 \\
\hline p-value ** & $<0.001$ & $<0.001$ & & 0.006 & $<0.001$ & & $<0.001$ & $<0.001$ & \\
\hline \multicolumn{10}{|l|}{ Working condition } \\
\hline Employed & $189(51.4)$ & $92(25.8)$ & $<0.001$ & $76(44.4)$ & $31(31.6)$ & 0.039 & $113(57.4)$ & $61(23.6)$ & $<0.001$ \\
\hline Unemployed & $207(27.1)$ & $168(26.5)$ & 0.777 & $133(32.9)$ & $38(22.0)$ & 0.008 & $74(20.6)$ & $130(28.1)$ & 0.013 \\
\hline Retired/Pensioner & $148(28.8)$ & $142(67.9)$ & $<0.001$ & $72(33.8)$ & $38(64.4)$ & $<0.001$ & $76(25.3)$ & $104(69.3)$ & $<0.001$ \\
\hline p-value ** & $<0.001$ & $<0.001$ & & 0.025 & $<0.001$ & & $<0.001$ & $<0.001$ & \\
\hline \multicolumn{10}{|l|}{ Anthropometric measures } \\
\hline \multicolumn{10}{|l|}{ Overweight/Obesity *** } \\
\hline No & $145(19.6)$ & $60(16.1)$ & 0.154 & $94(23.7)$ & $22(17.6)$ & 0.150 & $51(14.9)$ & $38(15.4)$ & 0.875 \\
\hline Yes & $294(38.5)$ & $224(32.9)$ & 0.027 & $149(44.2)$ & $58(34.7)$ & 0.042 & $145(34.0)$ & $166(32.3)$ & 0.589 \\
\hline$p$-value ** & $<0.001$ & $<0.001$ & & $<0.001$ & 0.001 & & $<0.001$ & $<0.001$ & \\
\hline \multicolumn{10}{|l|}{ Abdominal obesity } \\
\hline No & $206(26.8)$ & $71(19.6)$ & 0.009 & $130(31.0)$ & $24(21.4)$ & 0.048 & $76(21.8)$ & $47(18.8)$ & 0.374 \\
\hline Yes $(\geq 94 \mathrm{~cm}$ ठ or $\geq 80 \mathrm{~cm}$ \&) & $334(38.5)$ & 327 (39.5) & 0.668 & $149(41.0)$ & $82(38.1)$ & 0.490 & $185(36.7)$ & $245(40.0)$ & 0.256 \\
\hline p-value ** & $<0.001$ & $<0.001$ & & 0.003 & 0.002 & & $<0.001$ & $<0.001$ & \\
\hline \multicolumn{10}{|l|}{ Lifestyle } \\
\hline \multicolumn{10}{|l|}{ High alcohol consumption } \\
\hline No & $370(32.0)$ & $312(34.1)$ & 0.321 & $193(33.3)$ & $87(32.3)$ & 0.775 & $177(30.7)$ & $225(34.8)$ & 0.128 \\
\hline Yes & $174(35.6)$ & $90(31.5)$ & 0.244 & $88(42.1)$ & $20(32.8)$ & 0.191 & $86(30.7)$ & $70(31.1)$ & 0.924 \\
\hline p-value ** & 0.162 & 0.411 & & 0.023 & 0.947 & & 0.996 & 0.310 & \\
\hline \multicolumn{10}{|l|}{ Smoker } \\
\hline No & $415(32.7)$ & $326(32.2)$ & 0.794 & 209 (35.4) & $78(29.3)$ & 0.080 & $206(30.4)$ & $248(33.2)$ & 0.247 \\
\hline Yes & $129(34.3)$ & $76(40.2)$ & 0.169 & $72(36.4)$ & $29(45.3)$ & 0.201 & $57(32.0)$ & $47(37.6)$ & 0.314 \\
\hline $\mathrm{p}$-value ** & 0.567 & 0.032 & & 0.811 & 0.014 & & 0.673 & 0.341 & \\
\hline \multicolumn{10}{|l|}{ Physical activity } \\
\hline Sufficiently active & 299 (32.6) & $250(30.8)$ & 0.417 & $183(36.2)$ & $64(28.6)$ & 0.044 & $116(28.1)$ & 186 (31.6) & 0.236 \\
\hline Insufficiently active & $245(33.7)$ & $152(39.2)$ & 0.071 & $98(34.6)$ & $43(40.6)$ & 0.278 & $147(33.2)$ & 109 (38.7) & 0.133 \\
\hline $\mathrm{p}$-value ** & 0.615 & 0.004 & & 0.651 & 0.030 & & 0.106 & 0.039 & \\
\hline
\end{tabular}

* Chi-square test for difference between 2006 and 2016;

** Chi-square test for difference in 2006 and in 2016;

$\star \star \star$ BMI: body mass index $\geq 25 \mathrm{~kg} / \mathrm{m}^{2}$ for people less than 60 years and $\geq 27 \mathrm{~kg} / \mathrm{m}^{2}$ for those 60 years of age and older. 
Table 3

Factors associated with hypertension of the adult population of rural and urban areas according to the year of study, sociodemographic, anthropometric and lifestyle data. State Surveys of Noncommunicable Diseases, Pernambuco State, Brazil.

\begin{tabular}{|c|c|c|c|c|}
\hline Variables & $\mathrm{OR}_{\text {crude }}(95 \% \mathrm{Cl})$ & p-value & $\mathrm{OR}_{\text {adjusted }}(95 \% \mathrm{Cl})$ * & p-value \\
\hline \multicolumn{5}{|l|}{ Rural $(n=1,025)$} \\
\hline Age (years) & & $<0.001$ & & $<0.001$ \\
\hline $20-40$ & Ref. & & Ref. & \\
\hline $40 \mid-60$ & $2.54(1.87-3.46)$ & $<0.001$ & $2.56(1.89-3.47)$ & $<0.001$ \\
\hline$\geq 60$ & $3.90(0.88-17.38)$ & 0.074 & $4.05(0.91-18.08)$ & 0.067 \\
\hline Male & $1.79(1.21-2.65)$ & 0.003 & $1.79(1.21-2.64)$ & 0.004 \\
\hline Educational level (years of schooling) & & 0.001 & & 0.001 \\
\hline$\geq 12$ & Ref. & & Ref. & \\
\hline $8 \mid-12$ & $0.86(0.37-1.99)$ & 0.730 & $0.87(0.38-2.01)$ & 0.749 \\
\hline$<8$ & $2.19(1.24-3.86)$ & 0.007 & $2.21(1.26-3.89)$ & 0.006 \\
\hline Overweight/Obesity ** & $2.25(1.55-3.26)$ & $<0.001$ & $2.23(1.54-3.22)$ & $<0.001$ \\
\hline Abdominal obesity $* * *$ & $1.71(1.08-2.70)$ & 0.023 & $1.67(1.06-2.63)$ & 0.028 \\
\hline Smoker & $1.07(0.76-1.51)$ & 0.712 & - & - \\
\hline High alcohol consumption \# & $1.42(1.01-2.00)$ & 0.044 & $1.43(1.02-2.01)$ & 0.038 \\
\hline Insufficiently active \#\# & $0.85(0.63-1.16)$ & 0.305 & - & - \\
\hline \multicolumn{5}{|l|}{ Urban $(n=1,530)$} \\
\hline Age (years) & & $<0.001$ & & $<0.001$ \\
\hline $20 \mid-40$ & Ref. & & Ref. & \\
\hline $40 \mid-60$ & $4.45(3.42-5.78)$ & $<0.001$ & $4.41(3.40-5.73)$ & $<0.001$ \\
\hline$\geq 60$ & $14.34(4.31-47.66)$ & $<0.001$ & $14.44(4.38-47.65)$ & $<0.001$ \\
\hline Male & $1.98(1.47-2.66)$ & $<0.001$ & $2.03(1.52-2.71)$ & $<0.001$ \\
\hline Educational level (years of schooling) & & 0.009 & & 0.012 \\
\hline$\geq 12$ & Ref. & & Ref. & \\
\hline $8 \mid-12$ & $1.22(0.82-1.81)$ & 0.339 & $1.21(0.81-1.81)$ & 0.347 \\
\hline$<8$ & $1.59(1.18-2.15)$ & 0.002 & $1.56(1.16-2.10)$ & 0.003 \\
\hline Overweight/Obesity ** & $1.84(1.30-2.62)$ & 0.001 & $1.86(1.31-2.64)$ & 0.001 \\
\hline Abdominal obesity *** & $2.04(1.39-3.00)$ & $<0.001$ & $2.04(1.39-3.00)$ & $<0.001$ \\
\hline Smoker & $0.91(0.65-1.27)$ & 0.575 & - & - \\
\hline High alcohol consumption \# & $1.15(0.86-1.53)$ & 0.343 & - & - \\
\hline Insufficiently active \#\# & $1.04(0.80-1.35)$ & 0.69 & - & - \\
\hline
\end{tabular}

95\%Cl: 95\% confidence interval; OR: odds ratio; Ref.: reference.

Note: compared with 2006.

* Adjusted for year of study;

** Compared with body mass index $<25 \mathrm{~kg} / \mathrm{m}^{2}$ for people less than 60 years and $<27 \mathrm{~kg} / \mathrm{m}^{2}$ for those 60 years of age and older;

$* \star *$ Compared with waist circumference $<94 \mathrm{~cm}$ oै or $<80 \mathrm{~cm}$ \%;

\# Compared with moderate alcohol consumption: mean ingestion up to 2 drinks per day for men and up to 1 drink per day for women;

\#\# Compared with sufficiently active: at least 150 minutes of moderate-intensity aerobic physical activity or at least 75 minutes of vigorous-intensity aerobic physical activity distributed throughout the week or an equivalent combination of moderate- and vigorous-intensity activity. 
early stages, which affects individuals of age groups increasingly earlier, especially when associated with lack of information from the population 32 .

A literature review of published studies from 2003 to 2015, within which more than half were carried out in Brazil, identified that arterial hypertension is more prevalent among adults and elderly, African-native, obese, female subjects, with lower educational level, high sodium ingestion, sedentary lifestyle, stress, high alcohol consumption and smoking habits 33 . The present study shows that female from rural areas were around $44 \%$ less likely to have hypertension than male subjects, and $50 \%$ less likely in urban areas; however, hypertension prevalence increased significantly among female subjects in urban area, following a trend of inversion of risk related to sex. This trend was also found in a systematic analysis of population-based studies: prevalence in Brazil was 36\% in male and $33.8 \%$ in female in 2000 , and $28.1 \%$ and $38.5 \%$ in 2010 , respectively 31 . Regarding our study, it is worth noting that overweight increased significantly among female subjects in urban area $(\mathrm{p}<0.001)$, but not in rural area $\left(\mathrm{p}=0.123\right.$ ) between 2006 and 2015/2016, and that an increase about $10.3 \mathrm{~kg} / \mathrm{m}^{2}$ in BMI can double the risk of hypertension 34 .

The relationship between socioeconomic status and hypertension has been well established 15 as either a cardiovascular risk factor or a means to predict lifestyle 35,36. The socioeconomic statushypertension gradient appears to differ by development region with a positive gradient often seen in LMICs 17,29 and a negative in HICs 15 . The results of this study are contrary to those identified in LMICs, but this inverse association may indicate that the country reached an advanced development stage 19, as it has been observed in China with exception of some rural areas 17 . The data of a population-based study developed in Brazil showed that individuals with less than four years of schooling were almost twice as likely to present hypertension 37 , and, in this study, the magnitude of low education level was higher in rural areas.

The educational level is reported as the best marker 35 and it can modify the effect of other socioeconomic determinants 29 once well educated people are more likely to be employed, have a better work and economic conditions, social and psychological resources, and to adhere a healthier lifestyle 38. A low level of schooling is associated with the perception of stress and with high BMI and waist circumference, what contribute to the increase of blood pressure 16 .

Another important finding is that, awareness and control of hypertension improved substantially in rural areas so that they were like those of urban areas by 2015/2016. Thus, the urban-rural differences regarding the management of hypertension seem to have reduced in this period, and the temporal evolution was especially favorable in rural areas. In our study, hypertension awareness (68.4\%) and control (31.6\%) in 2015/2016 were similar to those reported in HICs (67\% and 28.4\%) by a pooled analysis of population-based studies 31 , although below the rates found in other specific studies performed in high income countries, such as Canada and United States, and in Central Asia, and in a better educated segment of the Brazilian population 39,40,41. In contrast to our findings, the proportion of individuals with controlled blood pressure in LMICs decreased from $8.4 \%$ in 2000 to $7.7 \%$ in 201031 worldwide, and the awareness and control of hypertension were significantly worse in rural areas of these regions 9 .

Among other factors, the progress in the management of hypertension in the state of Pernambuco during the decade of this study is probably due to improvements in health and living conditions, as well as poverty reduction, priority since 2002 20. The expansion on population coverage by Family Health Strategy (FHS), the primary care organization of the Brazilian health system, and the implementation of the Family Health Support Center integrating professional categories other than doctor, nurse and community health agents, was beneficial to mortality rates and strengthened the primary care 20,42 by expanding screening, diagnosis and monitoring networks. Moreover, since 2006, Brazil has had a more effective promotion of health policies, focusing on risk factors to encourage healthier eating habits, physical exercise, reduced alcohol consumption and smoking habits control 43.

FHS coverage increased greatly from 2000 to 2016 in Northeast Brazil 20, as well as the primary health care workforce from 2008 to 2013 44. However, the hypertension care network in the state of Pernambuco is still unsatisfactory, and the access to appropriate medication is low to average 45,46 , justifying the modest rate of successful control of hypertension in 2015/2016 (33.2\%, urban; $27.2 \%$, rural areas). 
In this study, the results on hypertension awareness and control may also have been influenced by the differences in the constitution of the samples in 2006 and 2015/2016, and by information biases, as the answers provided. The cross-sectional design, which precludes assessing causal relationships, together with the lack of variables related to health services access, comorbidities and other environmental and behavioral factors that may explain the prevalence of arterial hypertension, are also limitations to this study. Furthermore, the lower numbers of individuals evaluated in 2015/2016 due to financial difficulties, especially in the rural areas, may have compromised the internal validity of the results; yet, the numbers remain substantial to derive to conclusions.

Despite these limitations, the State Surveys of Noncommunicable Diseases are the only populationbased epidemiological research on this subject in urban and rural areas of the State of Pernambuco, marked by strong social inequalities. The samples were representative its population, and data collection was carefully planned and executed. In addition, the data of this research show a real and innovative approach to this problem in a poor region and in a context of social development, followed by political and economic reforms. These aspects need to be considered when interpreting these data and they indicate the need for more in-depth knowledge of this complex issue.

This study can be considered an important starting point for monitoring the indicators of hypertension and comparing with a future research, given the current context of economic and political crisis. Since 2014, this crisis, in addition to austerity measures, has been threatening improvements in the health of the population 20,47. The Constitutional Amendment n. 95 (EC 95/PEC 55/PEC 241), approved in December 2016, froze the federal budget over the next 20 years, including educational and health sectors 20,47,48. Furthermore, many social assistance and inequalities reduction programs, together with preventive health, are facing spending cuts 46 . Under these circumstances, it is to be feared that the disadvantages in access to services and health outcomes will increase in poor regions, such as the North and Northeast Brazil, and in lower education level groups 20.

In summary, the present data highlight a favorable temporal evolution in hypertension management and the stability in hypertension prevalence in recent years, mainly in rural areas, which are known all over the world to be most deprived. However, this evolution will need to be monitored in the years to come, as concern may be raised about the direction of health and epidemiological repercussions.

\section{Contributors}

N. P. Souza was responsible for the study conception, data preparation, statistical analysis, interpretation of data and writing of the manuscript. E. A. P. Cesse was responsible for study design, interpretation of data and review of the paper. W. V. Souza and M. Le Goff contributed with statistical analysis and interpretation of data. A. Fontbonne and M. N. S. C. Barreto contributed with data interpretation and the critical review of the manuscript. M. Batista Filho, C. Féart and P. I. C. Lira were responsible for study design, interpretation of data and review of the paper. All authors approved the final version of the text to be published.

\section{Additional informations}

ORCID: Nathália Paula de Souza (0000-0001-68268239); Eduarda Ângela Pessoa Cesse (0000-00015745-3981); Wayner Vieira de Souza (0000-00020939-9332); Annick Fontbonne (0000-0002-13028200); Maria Nelly Sobreira de Carvalho Barreto (0000-0002-3667-7676); Mélanie Le Goff (00000003-2848-6287); Malaquias Batista Filho (00000002-1490-0590); Catherine Féart (0000-00027959-1610); Pedro Israel Cabral de Lira (00000002-1534-1620).

\section{Acknowledgments}

The authors are greatly indebted to the many people in the Sate of Pernambuco who agreed to contribute their time to the data collection. 


\section{References}

1. Bloom DE, Cafiero ET, Jané-Llopis E, Abrahams-Gessel S, Bloom LR, Fathima S, et al. The global economic burden of non-communicable diseases. Geneva: World Economic Forum; 2011.

2. Marinho MGS, Cesse EAP, Bezerra AFB, Sousa IMC, Fontbonne A, Carvalho EF. Analysis of health care costs of patients with diabetes mellitus and hypertension in a public health reference unit in Recife - Brazil. Arq Bras Endocrinol Metab 2011; 50:406-41.

3. Ribeiro ALP, Duncan BB, Brant LCC, Lotufo PA, Millo JG, Barreto SM. Cardiovascular health in Brazil: trends and perspectives. Circulation 2016; 133:422-33.

4. World Health Organization. Global action plan for the prevention and control of noncommunicable diseases: 2013-2020. Geneva: World Health Organization; 2013.

5. Gakidou E, Afshin A, Abajobir AA, Abate KH, Abbafati C, Abbas KM, et al. Global, regional, and national comparative risk assessment of 84 behavioural, environmental and occupational, and metabolic risks or clusters of risks, 1990-2016: a systematic analysis for the Global Burden of Disease Study 2016. Lancet 2017; 390:1345-422.

6. Malta DC, Felisbino-Mendes MS, Machado IE, Passos VMA, Abreu DMX, Ishitani LH, et al. Risk factors related to the global burden of disease in Brazil and its Federated Units, 2015. Rev Bras Epidemiol 2017; 20 Suppl 1:217-32.

7. Beaney T, Schutte AE, Tomaszewski M, Ariti C, Burrell LM, Castillo RR, et al. May measurement month 2017: an analysis of blood pressure screening results worldwide. Lancet 2018; 6:736-43.

8. Malta DC, Santos NB, Perillo RD, Szwarcwald CL. Prevalence of high blood pressure measured in the Brazilian population, National Health Survey, 2013. Med J 2016; 134:163-70.

9. Chow CK, Teo KK, Rangarajan S, Islam S, Gupta R, Avezum A, et al. Prevalence, awareness, treatment, and control of hypertension in rural and urban communities in high-, middle-, and low-income countries. JAMA 2013; 310:959-68.

10. Hien HA, Tam NM, Tam V, Derese A, Devroey D. Prevalence, awareness, treatment, and control of hypertension and its risk factors in (Central) Vietnam. Int J Hypertens 2018; 2018:6326984.

11. Instituto Brasileiro de Geografia e Estatística. Atlas do Censo Demografico 2010. Rio de Janeiro: Instituto Brasileiro de Geografia e Estatística; 2013.

12. Programa das Nações Unidas para o Desenvolvimento; Fundação João Pinheiro; Instituto de Pesquisa Econômica Aplicada. Atlas do Desenvolvimento Humano no Brasil. http://www. atlasbrasil.org.br/2013/pt/consulta/ (accessed on 05/Aug/2019).
13. Programa das Nações Unidas para o Desenvolvimento; Fundação João Pinheiro; Instituto de Pesquisa Econômica Aplicada. Atlas de Desenvolvimento Humano: além das médias. Brasília: Programa das Nações Unidas para o Desenvolvimento/Fundação João Pinheiro/ Instituto de Pesquisa Econômica Aplicada; 2017.

14. Souza NP, Lira PIC, Fontbonne A, Pinto FCL, Cesse EAP. (Mal)nutrition and the new epidemiological trend in a context of development and inequalities. Ciênc Saúde Colet 2017; 22:2257-66.

15. Leng G, Jin Y, Li G, Chen L, Jin N. Socioeconomic status and hypertension: a meta-analysis. J Hypertens 2015; 33:221-9.

16. Chaix B, Bean K, Leal C, Thomas F, Havard S, Evans D, et al. Individual/neighborhood social factors and blood pressure in the RECORD Cohort study which risk factors explain the associations? Hypertension 2010; 55:769-75.

17. Busingye D, Arabshahi S, Subasinghe AK, Evans RG, Riddell MA, Thrift AG. Do the socioeconomic and hypertension gradients in rural populations of low and middle-income countries differ by geographical region? A systematic review and meta-analysis. Int J Epidemiol 2014; 43:1563-77.

18. Lobo LAC, Canuto R, Dias-da-Costa JS, Pattussi MP. Tendência temporal da prevalência de hipertensão arterial sistêmica no Brasil. Cad Saúde Pública 2017; 33:e00035316.

19. Reddy KS, Naik N, Prabhakaran D. Hypertension in the developing world: a consequence of progress. Curr Cardiol Rep 2006; 8:399-404.

20. Massuda A, Hone T, Leles FAG, Castro MC, Atun R. The Brazilian health system at crossroads: progress, crisis and resilience. BMJ Glob Health 2018; 3:e000829.

21. Brazilian Society of Cardiology. 7th Brazilian Arterial Hypertension Guideline. Arq Bras Cardiol 2016; 107(3 Suppl 3):1-83.

22. National Institutes of Health. The pratical guide identification, evaluation, and treatment of overweight and obesity in adults. Bethesda: National Institutes of Health; 2000.

23. World Health Organization. Consultation (TRS 894). Obesity preventing and managing the global epidemic. Geneva: World Health Organization; 2000.

24. Haskell WL, Lee I-M, Pate RR, Powell KE, Blair SN, Franklin BA, et al. Physical activity and public health: updated recommendation for adults from the American College of Sports Medicine and the American Heart Association. Circulation 2007; 116:1081-93.

25. Moreira JPL, Moraes JR, Luiz RR. Prevalence of self-reported systemic arterial hypertension in urban and rural environments in Brazil: a population-based study. Cad Saúde Pública 2013; 29:62-72. 
26. Lyra R, Silva RS, Montenegro Junior RM, Matos MVC, Cézar NJB, Fernandes VO, et al. High prevalence of arterial hypertension in a Brazilian Northeast population of low education and income level, and its association with obesity and metabolic syndrome. Rev Assoc Méd Bras 2012; 58:209-14.

27. Bezerra VM, Andrade ACS, César CC, Caiaffa WT. Comunidades quilombolas de Vitória da Conquista, Bahia, Brasil: hipertensão arterial e fatores associados. Cad Saúde Pública 2013; 29:1889-902.

28. Minelli C, Borin LA, Trovo MC, Reis GC. Hypertension prevalence, awareness and blood pressure control in Matao, Brazil: a pilot study in partnership with the Brazilian Family Health Strategy Program. J Clin Med Res 2016; 8:524-30.

29. Amegah AK, Näyhä S. Educational attainment modifies the association of wealth status with elevated blood pressure in the Ghanaian population. Heliyon 2018; 4:e00711.

30. Zhou B, Bentham J, Cesare MD, Bixby H, Danaei G, Cowan MJ, et al. Worldwide trends in blood pressure from 1975 to 2015: a pooled analysis of 1479 population-based measurement studies with 19.1 million participants. Lancet 2017; 389:37-55.

31. Mills KT, Bundy JD, Kelly TN, Reed JE, Kearney PM, Reynolds K, et al. Global disparities of hypertension prevalence and control: a systematic analysis of population-based studies from 90 countries. Circulation 2016; 134:44150.

32. Moura IH, Vieira EES, Silva GRF, Carvalho RBN, Silva ARV. Prevalência de hipertensão arterial e seus fatores de risco em adolescentes. Acta Paul Enferm 2015; 28:81-6.

33. Pinto IC, Martins D. Prevalence and risk factors of arterial hypertension: a literature review. Journal of Cardiovascular Medicine and Therapeutics 2017; 1:1-7.

34. Poorolajal J, Farbakhsh F, Mahjub H, Bidarafsh A, Babaee E. How much excess body weight, blood sugar, or age can double the risk of hypertension? Public Health 2016; 133:14-8.

35. Minor D, Wofford M, Wyatt SB. Does socioeconomic status affect blood pressure goal achievement? Curr Hypertens Rep 2008; 10:390-7.

36. Lam CSP. The socioeconomics of hypertension: how $\$ 50000$ may buy a drop in blood pressure. Hypertension 2011; 58:140-1.

37. Costa JSD, Barcellos FC, Sclowitz ML, Sclowitz IKT, Castanheira M, Olinto MTA, et al. Prevalência de hipertensão arterial em adultos e fatores associados: um estudo de base populacional urbana em Pelotas, Rio Grande do Sul, Brasil. Arq Bras Cardiol 2007; 88:54-9.
38. Ross $\mathrm{CE}, \mathrm{Wu} \mathrm{C}$. The links between education and health. Am Sociol Rev 1995; 60:719-45.

39. Chor D, Ribeiro ALP, Carvalho MS, Duncan BB, Lotufo PA, Nobre A, et al. Prevalence, awareness, treatment and influence of socioeconomic variables on control of high blood pressure: results of the ELSA-Brasil Study. PLoS One 2015; 10:1-14.

40. Joffres M, Falaschetti E, Gillespie C, Robitaille C, Loustalot F, Poulter N, et al. Hypertension prevalence, awareness, treatment and control in national surveys from England, the USA and Canada, and correlation with stroke and ischaemic heart disease mortality: a cross-sectional study. BMJ Open 2013; 3:e003423.

41. Supiyev A, Kossumov A, Utepova L, Nurgozhin T, Zhumadilov Z, Bobak M. Prevalence, awareness, treatment and control of arterial hypertension in Astana, Kazakhstan. A cross-sectional study. Public Health 2015; 129:948-53.

42. Hone T, Rasella D, Barreto M, Atun R, Majeed A, Millett C. Large reductions in amenable mortality associated with Brazil's primary care expansion and strong health governance. Health Aff 2017; 36:149-158.

43. Secretaria de Atenção à Saúde, Secretaria de Vigilância em Saúde, Ministério da Saúde. Política Nacional de Promoção da Saúde: PNPS: revisão da Portaria MS/GM no 687, de 30 de março de 2006. Brasília: Ministério da Saúde; 2015.

44. Carvalho MN, Gil CRR, Costa EMOD, Sakai MH, Leite SN. Needs and dynamics of the Primary Healthcare workforce in Brazil. Ciênc Saúde Colet 2018; 23:295-302.

45. Barreto MNSC, Cesse EAP, Lima RF, Marinho MGS, Specht YS, Carvalho EMF, et al. Análise do acesso ao tratamento medicamentoso para hipertensão e diabetes na Estratégia de Saúde da Família no Estado de Pernambuco, Brasil. Rev Bras Epidemiol 2015; 18:413-424.

46. Costa JMBS, Silva MRF, Carvalho EF. Avaliação da implantação da atenção à hipertensão arterial pelas equipes de saúde da família do município do Recife (PE, Brasil). Ciênc Saúde Colet 2011; 16:623-33.

47. Doniec K, Dall'Alba R, King L. Brazil's health catastrophe in the making. Lancet 2018; 392:731.

48. Noronha JC, Noronha GS, Pereira TR, Costa AM. The future of the Brazilian Health System: a short review of its pathways towards an uncertain and discouraging horizon. Ciênc Saúde Colet 2018; 23:2051-60. 


\section{Resumo}

O estudo teve como objetivo avaliar a evolução da prevalência, conhecimento e controle da hipertensão arterial ao longo de 10 anos no Estado de Pernambuco, Nordeste do Brasil. Foram realizados dois estudos transversais em amostras aleatórias em domicílios em áreas urbanas e rurais, em 2006 e 2015/2016, incluindo adultos com 20 anos ou mais. A hipertensão arterial foi definida como pressão sistólica de pelo menos $140 \mathrm{mmHg}$ ou pressão diastólica de pelo menos $90 \mathrm{mmHg}$ ou o uso referido de medicação anti-hipertensiva. Foi realizada análise de regressão logística para estimar a influência dos determinantes sociais, comportamentais e antropométricos sobre a hipertensão. Os fatores sociais e comportamentais melhoraram ao longo da década em questão, mas as taxas de sobrepeso e de obesidade abdominal aumentaram. Aproximadamente um terço da população adulta de Pernambuco apresentava hipertensão em 2006, e essa prevalência foi mantida em 2015/2016. Nas áreas rurais, o conhecimento da hipertensão aumentou de 44, 8\% em 2006 para 67,3\% em 2015/2016, e o controle aumentou de $5,3 \%$ para $27,1 \%$, de maneira que o conhecimento e o controle foram muito semelhantes entre áreas urbanas e rurais em 2015/2016. Após ajustar para potenciais fatores de confusão, a probabilidade de apresentar hipertensão mais do que dobrou entre homens $(O R=2,03 ; p<0,001)$, adultos jovens $(O R=4,41 ; p<0,001)$ e idosos $(O R=14,44 ; p<0,001)$, e entre aqueles com obesidade abdominal $(O R=2,04 ; p<0,001)$ nas áreas urbanas e adultos jovens $(O R=2,56 ; p<0,001)$, pessoas com menor escolaridade $(O R=2,21$; $p=0,006)$ e pessoas com sobrepeso $(O R=2,23 ; p$ $<0,001)$ nas áreas rurais. Apesar da evolução favorável no manejo da hipertensão no Estado de Pernambuco, são necessárias medidas de saúde pública focadas nas populações mais vulneráveis, principalmente nas áreas rurais, para melhorar a prevenção primária e impedir o aumento da hipertensão.

Hipertensão; Prevalência; Conscientização; Controle; Adulto

\section{Resumen}

El objetivo de este estudio fue evaluar la evolución de la prevalencia, concienciación y control de la hipertensión durante 10 años en el Estado de Pernambuco, Nordeste brasileño. Se llevaron a cabo dos estudios transversales, basados en muestras aleatorias de hogares ubicados en áreas urbanas y rurales, en 2006 y 2015/2016, implicando a adultos con 20 años y más edad. La hipertensión fue definida como presión arterial sistólica de al menos $140 \mathrm{mmHg}$, presión arterial diastólica de al menos $90 \mathrm{mmHg}$, o el consumo informado de medicación antihipertensiva. Se realizó un análisis de regresión logística para estimar la influencia de los determinantes sociales, comportamentales y antropométricos en la hipertensión. Los factores sociales y comportamentales mejoraron durante este periodo de 10 años, a pesar de que sobrepeso y la obesidad abdominal aumentaron. Aproximadamente un tercio de la población adulta de Pernambuco sufría hipertensión en 2006 y esta prevalencia se mantuvo en 2015/2016. En las áreas rurales, la concienciación sobre la hipertensión aumentó de un 44,8\% en 2006, a un 67,3\% en 2015/2016,y el control de un 5,3\% a un 27,1\%, así pues la concienciación y control fueron similares en áreas urbanas y rurales en 2015/2016. Tras el ajuste para los factores potenciales de confusión, la probabilidad de sufrir hipertensión es más del doble entre hombres $(O R=2,03 ; p<0,001)$ de mediana edad $(O R=4,41 ; p<0,001)$ e individuos de edad avanzada $(O R=14,44 ; p<0,001)$, y aquellos que sufrieron obesidad abdominal $(O R=2,04 ; p<0,001)$ en áreas urbanas, $y$ entre los de mediana edad $(O R=2,56 ; p<0,001)$, individuos menos educados $(O R=2,21 ; p=0,006)$ y quienes sufrían sobrepeso $(O R=2,23$; $p<0,001)$ en áreas rurales. $A$ pesar de la evolución favorable en la gestión de la hipertensión en Pernambuco, se necesitan medidas de salud pública que se centren en las poblaciones vulnerables, principalmente en las áreas rurales, para mejorar la prevención primaria y frenar el incremento de la enfermedad.

Hipertensión; Prevalencia; Concienciación; Control; Adulto
Submitted on $12 / \mathrm{Feb} / 2019$

Final version resubmitted on 27/Aug/2019

Approved on 23/Sep/2019 